Nadwa : Jurnal Pendidikan Islam

Vol. 13, No.1 (2019)

Accredited by Ristekdikti based on Decree No. 51/E/KPT/2017

DOI: http://dx.doi.org/10.21580/nw.2019.1.1.3899

\title{
The Relevance Of Al-Ghazali's Tazkiyatun-Nafs Concept With Islamic Education In The Millennial Era.
}

\section{Musrifah}

STAI Brebes Central Java, Indonesia

ifahmusripah@yahoo.co.id

\begin{abstract}
This study aims to know the relevance of Al-Ghazali's tazkiyatun-nafs concept to Islamic education. This study uses the library research method with content analysis. The results showed that there were two relevance of al Ghazali's thinking about tazkiyatunnafs towards Islamic Education, namely first, that the purity of soul (tazkiyatun nafs) in Islamic education became a basic and very important thing for students to acquire useful knowledge. Science comes from Allah Swt The Most Holy. Second, A healthy soul as a result of tazkiyatunnafs is the key to the success of students amid the millennial life that has a very rapid change through information technology
\end{abstract}

Key terms: Tazkiyatunnafs; millennial era; al ghazali;

\section{Abstrak}

Penelitian ini bertujuan untuk mengatahui relevansi konsep tazkiyatun-nafs AlGhazali dengan pendidikan Islam. Penelitian ini menggunakan metode library research dengan content analysis. Hasil penelitian menunjukkan bahwa Relevansi pemikiran al Ghazali tentang tazkiyatunnafs terhadap Pendidikan Islam di era millennial ada dua yaitu pertama, kebersihan jiwa (tazkiyatun nafs) al Ghazali dalam pendidikan Islam menjadi hal yang bersifat dasar dan sangat penting untuk dimiliki anak didik agar memperolah ilmu yang bermanfaat. Karena Ilmu itu datangnya dari Allah Swt yang Maha Suci, shalatnya jiwa, dan peribadatannya batin kepada Allah Swt. Kedua, jiwa yang sehat hasil dari tazkiyatun-nafs merupakan kunci bagi kesuksesan anak didik ditengah kehidupan millennial yang mempunyai sifat perubahan yang sangat cepat melalui teknologi informasi

Kata Kunci Pendidikan Islam; zaman millennial; psikologi Islam; moral:

ISSN 1979-1739 (P) ; ISSN 2502-8057 (E).

(c) 2019 Nadwa : Jurnal Pendidikan Islam | UIN Walisongo.

Accredited by Ristekdikti based on Decree No. 51/E/KPT/2017

http://journal.walisongo.ac.id/index.php/nadwa 


\section{6 | Musrifah}

\section{Background}

Islamic Education has the main goal of forming morality in students. While characters are formed due to internal and external factors. Therefore it is important to discuss the relationship between Islamic Education, as a person's attempt to provide the circumstances to have al kariimah morals by discussing the knowledge of the soul in this case al Ghazali's thinking about tazkiyatun nafs which also aims to cleanse the soul of things that pollute so as to create morality al karimah morality too.

Tazkiyatun nafs (Soul Cleansing) is included in the core discussion in Islamic Psychology. A person whose soul is clean/pure is expected to influence a person's good behavior. Like a lake that has clean water, it will also drain clean water into river channels so that it can be used by humans and other creatures of God.

Various definitions of Life Sciences (psychology) have been carried out by several experts. Among them is Zakiah Daradjat who argues that a person's behavior that appears outward occurs because it is influenced by his beliefs1. Abdul Aziz said that Psychology is a continuation of the study of human behavior in everyday life. Many concepts in psychology can be determined originating from the life of human relations.2

On the other hand, education is an effort to shape human personal through a long process in which the results cannot be known immediately, in contrary from forming non-living things that can be done in accordance with the wishes of the maker. In a broad sense, education is personal development in all aspects,

1 Abuddin Nata, Metodologi Studi Islam (Jakarta: RajaGrafindo Persada, 2002), 50 .

2 Abdul Aziz Ahyadi, Psikologi Agama Kepribadian Muslim Pncasila (Bandung, Sinar Baru Algensindo, 2001),23. (Bandung: Sinar Baru Algensindo, 2001), 23. 
which includes education by oneself, education by the environment, and education by others (teachers). All aspects include physical, spiritual and mental.3

The Prophet has encouraged people to believe and do good deeds and have good character according to Islamic teachings with various methods and approaches. On one side, we see that Islamic education is not only theoretical, but also practical. The teachings of Islam do not separate faith from righteous deeds. Therefore Islamic education is also as faith education and charity education. Initially Islamic education was carried out by the Prophets, then carried out by muslim scholars as successors to their duties and obligations. 4

Al-Ghazali explained that the intellect is a means for gaining knowledge of morality and good behavior that cannot be realized without knowledge. Knowledge arises from the displacement of intellect or ' $a q l$ which is the rational power of man, the power that distinguishes man and animal. AL-Ghazali's researches cover almost all basic aspects of psychology, for example dealing with various aspects of motivation, meaning and significance of self or soul, soul power, sharing of sensory power into internal and external power or power possessed by humans and also possessed by animals, reason and willingness, various kinds of emotions and feelings, abnormal behavior, interconnected individuals with society and living alone (isolating themselves).

The concept of the tazkiyatun-nafs according to Al-Ghazali tends to teach about mental cleanliness. Humans, according to AlGhazali, were created by Allah as a creature consisting of soul (soul), which can be known by spiritual insight, and body. The

3 Ahmad Tafsir, Ilmu Pendidikan dalam Perspektif Islam, 2 ed. (Bandung: PT. Remaja Rosdakkarya, 1994), 26.

4 Zakiah Daradjat, Ilmu Pendidikan Islam, (Jakarta, Bumi Aksara, 2017 (Jakarta: Bumi Aksara, 2017), 28. 
soul that is the core of human nature is a very subtle Rabbani spiritual being (Lathifa ruhhaniyyah). The terms used by AlGhazali for the soul are qalb, ruh, nafs, and aql. It is interesting to find common ground between the Sufi perspective on the AlGhazali's concept of tazkiyatun-nafs and its relevance to present and future Islamic education.

This qualitative research approach uses a library reseach, meaning that the pure literature of the data used uses primary and secondary data. The analysis used uses content analysis.5

\section{Biography and Work of Al-Ghazali}

Al-Ghazali has the full name Abu Hamid Muhammad ibn Muhammad ibn Ahmad Al-Ghazali Al-Thus. He is a genuine Persian. Born in 450 AD 1058 in Thus (now near Meshed), a small city in the Iranian region.6 His parents gave him name Muhammad bin Muhammad bin Ahmad Al-Ghazali. Then, after being married and blessed with a son named Hamid, he was called by Abu Hamid. While the names of Muhammad, which are mentioned in a row and the the call of Al-Ghazali in his full name, containing the historical background of his life. The first name of Muhammad is his own name and then his father's name and finally his grandfather.7

His educational background began with the learning of Qur'an to his own father. After the death of his father, Al Ghazali and his brother were entrusted to his father's friend, Ahmad bin Muhammad Ar-Razikani, a great Sufi where AL-ghazali learns

5 Norman K Denzin dan Yvonna S Lincoln, Handbook Of Qualitative Research, 1 ed. (Yogyakarta: Pustaka Pelajar, 2009), 498.

6 Harun Nasution, Islam Ditinjau dari Berbagai Aspeknya, 2 (Jakarta: UI Press, 2002), 49.

7 Amin Syukur Masyharudin, Intelektualisme Tasawuf: Studi Intelektualisme Tasawuf Al-Ghazali (Yogyakarta: Pustaka Pelajar, 2002), 126. 
about the Qur'an, Hadith, the science of Fiqh, the spiritual life and poems about mahabah (love) to Allah. According to Zubaidi, a commentator of Al-Ghazali, explained that Al-Ghazali studied science from Imam Al-Haramain. He was able to exchange ideas with all branches of sciences, even he had written books in various sciences. 8

Al-Ghazali was different from other philosophers, he was not only concerned with philosophy but also about theology and sufism law. However, he was more Sufi than the philosopher.In the medieval Western world, Al-Ghazali was known as Abuhamet and Algazel. In the Islamic world he was given the title of Hujjatul Islam. Al-Ghazali was the last major philosopher in the eastern Islamic world. 9 Al-Ghazali's writings, totaling 47 pieces, can all be grouped into; (1) philosophy and theology, (2) fiqh and ushul fiqh, (3) moral and mysticism, and hermeneutics.

\section{Al-Ghazali's Tazkiyatun-nafs and the Relevance to Islamic Education}

Humans according to Al-Ghazali, created by Allah as a creature consisting of (spirit, which can be known by spiritual insight) and body. The terms used by Al-Ghazali for the soul are qalb, ruh, nafs and aql. Each term has two meanings, one means "soul" or "spirit" while the second meaning is different for each term. 10

Al-Ghazali also discusses differences of soul and body, and this is closely related to ethics. According to his view, the soul is a substance (jawhar) and not a state (ardh), so that it is in itself.

8 Syukur Masyharudin, 129.

9 Nasution, Islam Ditinjau dari Berbagai Aspeknya, 51.

10 Syukur Masyharudin, Intelektualisme Tasawuf: Studi Intelektualisme Tasawuf Al-Ghazali, 141-44. 
Bodies depend on the soul and not vice versa. The soul is different from the body in other matters. The soul is in the spiritual realm, while the body is in the material realm.11

The common term of mental health used by Al-Ghazali is Tazkiyatun-Nafs. The term of Tazkiyatun-Nafs means the purification of the soul from all illnesses and defects, realizing various subjects to it, and making asma' and the nature of God as morality. The soul can become holy when someone performs various acts of worship (eg prayer, infaq, fasting, hajj, dzikir, and recitations).12 Tazkiyatun-Nafs briefly means: cleansing the soul of polytheism and its branches, realizing its sanctity with monotheism and its branches and making the names of Allah as good morals by imitating the morality of the Prophet.13

Al-Ghazali's attention to moral education for children is very large. He explained that the essence of education is actually nothing but a process of mutual influence between instincts (fitrah) with the environment. According to Al-Ghazali, morality and morals of students can be influenced by education and good advice. As AL-Ghazali said, ""If the morality does not accept change, surely the fatwa, advice and education are empty". From this, it seems that Al-Ghazali has the belief that with education many things can be done, such as improving, perfecting and directing morals and purifying their souls.

According to Al-Ghazali, training children to have good morals is basically the responsibility of their parents. This opinion is strengthened by quoting the Qur'anic verse. "O ye who believe,

11 M.Abul Quasem, Etika Al-Ghazali (Bandung: Pustaka, 2000), 37.

12 Al-Ghazali, Intisari Ihya Ulumuddin Mensucikan Jiwa Konsep Tazkiyatun-Nafs Terpadu, diseleksi disusun ulang oleh Sa'id Hawwa, terj. Aunur Rofiq Shaleh Tamhid, (Jakarta: Rabbani Press, 2011), vii.

13 Ahyadi, Psikologi Agama Kepribadian Muslim Pncasila (Bandung, Sinar Baru Algensindo, 2001),23., 27. 
take care of yourself and your family from the fire of hell whose fuel is man and stones." School teachers are also responsible for this within certain limits. The training method is the same as training adults to have good character. However, the emphasis on the two methods is different in the case of adults where selfcultivation is the basic method of achieving good morals and therefore gets greater pressure than association. , on the contrary in children, protecting them from bad association is considered as the basis (practice) for good morals. Therefore, most teaching for children is through imitation. 14

In accordance with the opinion of AL-Ghazali above, it can be concluded that children are trustworthy and must be guarded and educated to achieve the virtues in life and draw closer to Allah. All babies born into this world, like a pearl that has not been measured and yet shaped but very high value. So it is his parents who would carve and shape it into high-quality pearls and are liked by everyone. So, the dependence of children on their education, including their parents, is very clear.

Islamic education experts have agreed that the purpose of education and teaching is not to fulfill the brain of students with all kinds of knowledge that they do not yet know, but the intention is to educate their morals and souls, instill a sense of fadhilah (virtue), familiarize them with high decency, prepare them for something that is entirely holy, sincere and honest. So the main purpose of Islamic education is to educate manners, and mental education. All subjects must contain moral lessons, each teacher must pay attention to morals, each teacher must think of religious morals before the others because religious morals are high morals, while noble morals are the pillars of Islamic education. Al-Ghazali argues: the purpose of education is to get closer to

14 Quasem, Etika Al-Ghazali, 102-3. 


\section{2 |Musrifah}

Allah, not rank and boast with friends. So education is not out from moral education. 15

Furthermore, Al-Ghazali describes that there are two methods in moral education; the first is utilizing prevention and avoidance, which is intended for children to avoid association and lousy environment. Students should be taken care of and kept away from friends who have bad character, atmosphere and habits, such as sleeping in the morning, dressing disrespectfully, bringing food and drinks with their left hand, learning lazily, complaining to others, lying and so forth. The second is doing as habituation. Doing in practice is more shown to concern children in learning and deepening knowledge and familiarizing good and commendable actions. Children should be preoccupied with studying the Qur'ran, hadiths, and stories or stories of pious people so that they are embedded in the soul of the child that there is a sense of love for them. They should also be always educated to be obedient to both their parents, to the people who are older than him, and to their educators. If children have been old enough (baligh), they should be taught about the secrets of noble behavior with the intention that obedience to God will be stronger.

Basically, the thing emphasized by Al-Ghazali more is how to prevent the habits recommended by Al-Ghazali to parents and teachers and most of them are as the form of prevention. It is due to his religious foundation as a Sufi who believes that efforts to prevent immoral behavior or bad deeds that should be prioritized. In the language of ushul fiqh, it is stated that restricting the coming of damage is prioritized than efforts to gain benefit.

For this reason, AL-Ghazali emphasized for prevention rather than for habituation. Besides that, no one can abandon the prohibition except the shiddiqin people. It can be concluded that

15 Athiyyah Al-Arbasyi, Dasar-dasar Pokok Pendidikan Islam (Jakarta: Bulan Bintang, 2002), 1. 
the prevention in the days of children is the most effective foundation to be planted in heart and in practice firmly.

Al-Ghazali's attention to children's moral formation, of course, is considerable as an exclusive feature in the concept of education. The writer also presents a description of the ways recommended by Al-Ghazali in the effort of moral formation. AlGhazali stated that the nature and character in children are always growing and developing. In this case, the child needs a lot of care and improvement. This effort was carried out by utilizing education and moral formation, which AL-Ghazali considered that it was not an easy job, although he believed that education can change morals within some specified extent.

Among several methods AL-Ghazali believed that it can indeed to keep a child away from futile deeds and insanity, is to fill activities in his empty time. So it is necessary to afford some reasonable means to fill this empty time according to his view by familiarizing the child with reading, especially reading the Qur'an, the Hadiths of the Prophet, biographies of pious people and matters of their lives. It means that it is embedded with the soul of love from the good people who are preserved from poems, novels that contain longing for romance, and so on. 16

Al-Ghazali's opinion in the broad context of putting an ethical principle for moral education is not only related to individual morality, but also faith to places foster ways of getting along with among others, as well as a belief for community education.

This Al-Ghazali's viewpoint this matter can be concluded that he is among those who pay more attention to fostering relationships between other human beings, which are based on affection, love each other, and mutual respect and maintain politeness in the association among community members. In

16 Al-Arbasyi, 78. 


\section{$24 \mid$ Musrifah}

general, these are all the symptoms that are considered as the main dimensions of democratic life that have been addressed by Islam. 17

In the relevance in education, students have a lot of manners and duties (wazhifah) physically, which are compiled by AlGhazali in ten parts, those are:

The first is prioritize the sanctity of the soul from the bad morals and ugliness because the knowledge is the worship in the heart, the prayer of the soul, and the inner worship to God.

The second is to reduce their attachment to the world business because of the busy and turn away bonds. It is since if the mind is divided, it is difficult to know a different nature. Therefore, we cannot get a part of science before we give the whole of our soul.

Third, do not be arrogant to people who have the knowledge and do not act arbitrarily against the teacher, even he must surrender all his affairs to the teacher and Allah SWT and obey his advice like a sick person who is ignorant to follow the advice of a doctor who is full of affection and proficiency.

Fourth, people who pursue knowledge at an early stage must guard themselves against listening to disputes between humans, both what they practice, including world science or the hereafter.

Fifth, someone who demands knowledge cannot leave a branch of knowledge that is commendable, or one type of science, unless he must consider carefully and pay attention to his purpose and purpose.

Sixth, do not pursue all fields of science at once but maintain the sequence and begin with the most important.

17 Al-Arbasyi, 86. 
Seventh, do not enter a branch of science before mastering the previous branch of science, because science is arranged in sequence, some of which are ways for others.

Eighth, should know the causal factors by which he can identify the noblest knowledge, what he means is two things: first glory results, both robustness and the power of the argument. It looks like religion and medicine. The result of religious knowledge is eternal life, while the results of medical science are mortal life. Thus, the science of religion is nobler.

Ninth, students in the world aim to decorate and beautify their hearts with virtue and in the hereafter, namely to draw closer to God and raise themselves to be able to be close to the highest beings of the angels and those who are brought near (muqarrabin).

Tenth, should know the relation of science to prioritize the high again nearer than the distant, and that which is essential than the others.

The duties of supervisors and instructors are as follows:

1. Compassion to students and treat them like children;

2. Modeling the Prophet. By not asking for wages for teaching, it is not intended to seek rewards or thanks, but to teach solely because of God and taqarrub to Him.

3. Do not leave advice to students at all, such as prohibiting it and trying to move to a level before it has the right to receive it, and explore hidden science before mastering explicit knowledge. Then remind the students that the purpose of seeking knowledge is taqarrub to Allah Ta'ala not to gain power, position, and competition;

4. Prevent students from despicable morals, indirectly and openly as much as possible, and with love not with reproach;

5. Teachers who pursue some of the knowledge should not denounce the sciences that are not practiced; 
6. Limiting according to the ability of students' understanding, not conveying to him what cannot be reached by his intellectual skills so as not to make him reluctant or burdensome to his mind, because he emulated the Prophet;

7. Students whose skills are limited should be conveyed to him things that are clear and following him;

8. The teacher must carry out his knowledge, i.e., his actions do not deny his words, because knowledge is known to the eye of the heart (bashirah).18

From the description above it can be concluded that the purpose of Islamic education according to Al-Ghazali is to worship from taqarrub to Allah, and tazkiyatun nafs can reach the perfection of happiness of the world and the hereafter. From a clean soul, good behavior will emerge based on the taqarrub ilallah. From good practice based on taqarrub ilallah, happiness and calm will appear and pleasure from Allah SWT.

As explained that in achieving the ultimate goal of education, it cannot be done at once but gradually, and each stage must go to the same purpose. The success or failure of Islamic education is influenced by all the factors that support the implementation. If problems arise in Islamic education, then we must be able to clarify the issues we face into the real factors. 19

The relevance of al Ghazali's thinking about the tazkiyatunnafs is that mental cleanliness (tazkiyatun nafs) in Islamic education is the basis of education and is very important for students to have useful knowledge. Because Science comes from Allah SWT and requires knowledge is the worship of the heart, prayer of the soul,

18 Al-Ghazali, Intisari Ihya Ulumuddin Mensucikan Jiwa Konsep Tazkiyatun-Nafs Terpadu, diseleksi disusun ulang oleh Sa'id Hawwa, terj. Aunur Rofiq Shaleh Tamhid, 15-23.

19 Nur Ubiyati, Ilmu Pendidikan Islam (IPI) (Bandung: Pustaka Setia, 2001), 124. 
and the devotion of the heart to Allah, then the students in Islamic education are also seen as children who have the potential of Allah to be useful (fitrah). Imam Al Ghazali has provided a very valuable guideline for a student who wants to succeed in Islamic education by carrying out ten (10) principles which in essence that cleansing the soul of things that are devoted to Allah SWT is the key to getting useful knowledge. Likewise, a teacher who educates must also maintain mental cleanliness and cleanliness of intentions in carrying out education, so that the goal of education to shape the morals of students can be achieved as the morality that has been exemplified by the Prophet Muhammad SAW.

Whereas the relevance of the concept of tazkiyatun-nafs AlGhazali for Islamic education in the millennial era, which is a healthy soul as a result of tazkiyatun-nafs, it is the key to the success of students amid the millennial life that has a very rapid nature of change through information technology. Information that comes from various sources must be filtered with a clear heart and with sincere intentions to get the pleasure of Allah SWT. Thus Islamic education and the concept of tazkiyatun nafs are closely related and the tazkiyaatunafs occupy the core position in Islamic education both past, present, and future and do not conflict with the concept of "long life education."

Today's education is education that is equipped with modern tools, which are standardized on competence, not just understanding and mastering the material. Humans still do tazkiyatun-nafs and need a clean soul because that way, humans will achieve perfection in life, in other words being "perfect human beings" with a balanced life by religious and State goals.

\section{Conclusion}

In general, Al-Ghazali is a figure of philosophy, Sufism, professor, and psychologist, from which one of his books is "The 
Essence of Ihya Ulumuddin Al-Ghazali," known as tazkiyatun$n a f s$, that it is necessary to be done by humans to achieve a perfect life with full of knowledge and charity.

There are two categories of the relevance of al Ghazali's thinking about tazkiyatun nafs, those are the first, that mental purifying (tazkiyatun nafs) in Islamic education becomes an essential and significant thing for students to obtain useful knowledge. For the reason that the knowledge comes from Allah SWT, and getting the knowledge is the worship of the heart, prayer of the soul, and the devotion of the heart to Allah SWT, then students in Islamic education are also seen as children who have the potential of Allah SWT to be good (fitrah). Imam Al Ghazali has provided a very valuable guideline for a student who wants to succeed in Islamic education by carrying out ten (10) principles which in essence that purifying the soul of things that are devoted to Allah SWT is the key to getting useful knowledge. Likewise, a teacher who educates them should maintain mental and intentional purifying in carrying out education, so that the goal of education to shape the morals of students can be achieved as the morality that has been exemplified by the Prophet Muhammad SAW. The second, that the relevance of the concept of tazkiyatun-nafs Al-Ghazali for Islamic education in the millennial era, namely a healthy soul as a result of tazkiyatun-nafs is the key to the success of students in the millennial life that has a very rapid nature of change through information technology. Information that comes from various sources must be filtered with a clear heart and with sincere intentions to get the pleasure of Allah SWT. Thus Islamic education and the concept of tazkiyatun nafs are closely related, and the tazkiyaatunafs occupy a core position in Islamic education in the past, the present, and the future 
Therefore, the concept of tazkiyatun-nafs is an appropriate concept that can be used as an approach in Islamic education both for the current and the future, and if applied in the concept of present education, it is necessary to implement a lot of innovation in accordance with the global era.

\section{References}

Ahyadi, Abdul Aziz. Psikologi Agama Kepribadian Muslim Pncasila, Bandung: Sinar Baru Algensindo, 2001.

Al-Arbasyi, Athiyyah. Dasar-dasar Pokok Pendidikan Islam. Jakarta: Bulan Bintang, 2002.

Al-Ghazali. Intisari Ihya Ulumuddin Mensucikan Jiwa Konsep Tazkiyatun-Nafs Terpadu, diseleksi disusun ulang oleh Sa 'id Hawwa, terj. Aunur Rofiq Shaleh Tamhid,. Jakarta: Rabbani Press, 2011.

Daradjat, Zakiah. Ilmu Pendidikan Islam, (Jakarta, Bumi Aksara, 2017. Jakarta: Bumi Aksara, 2017.

Denzin, Norman K, dan Yvonna S Lincoln. Handbook Of Qualitative Research. 1 ed. Yogyakarta: Pustaka Pelajar, 2009.

Nasution, Harun. Islam Ditinjau dari Berbagai Aspeknya,. 2. Jakarta: UI Press, 2002.

Nata, Abuddin. Metodologi Studi Islam. Jakarta: RajaGrafindo Persada, 2002.

Quasem, M.Abul. Etika Al-Ghazali. Bandung: Pustaka, 2000. 
$30 \mid$ Musrifah

Syukur Masyharudin, Amin. Intelektualisme Tasawuf: Studi Intelektualisme Tasawuf Al-Ghazali. Yogyakarta: Pustaka Pelajar, 2002.

Tafsir, Ahmad. Ilmu Pendidikan dalam Perspektif Islam. 2 ed. Bandung: PT. Remaja Rosdakkarya, 1994.

Ubiyati, Nur. Ilmu Pendidikan Islam (IPI). Bandung: Pustaka Setia, 2001. 